\title{
Política do ódio e a nova ordem de violências
}

\author{
AB'SÁBER, Tales. \\ Dilma e o ódio político. \\ São Paulo: Hedra, 79 p., 2015.
}

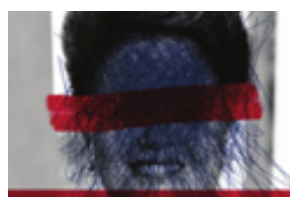

DILMA

ROUSSEFF

EOÓDIOPOLÍTICO

wartares

Resumo: Escrito no calor do momento das manifestações, o ensaio Dilma Rousseff e o ódio político constrói um panorama sintético das escolhas e falhas recentes do Partido dos Trabalhadores. Ao apontar a força do poder carismático do ex-presidente Lula, a obra debate os impactos simbólicos das administrações petistas na sociedade brasileira e apresenta uma nova ordem de violências advindas da emergência de uma direita organizada, agressiva e produtiva que carrega o ódio como estandarte.

Palavras-chave: política; Dilma Rousseff; Partido dos Trabalhadores; democracia.

Abstract: Politics of hate and the new order of violence - Written in the moment of the protests, the book Dilma Rousseff e o ódio político builds a synthetic overview of the choices and recent failures of the Partido dos Trabalhadores. By pointing the strength of the charismatic power of former President Lula, the work discusses the symbolic impact of PT administrations in Brazilian society and presents a new order of stemming violence of the emergence of a new organized, aggressive and productive right that carry hate as flag.

Keywords: politics; Dilma Rousseff; Partido dos Trabalhadores; democracy. 
Como lidar com o imenso impacto simbólico das administrações petistas? Para Tales Ab'Sáber, psicanalista e professor de Filosofia da Psicanálise na Universidade Federal de São Paulo (Unifesp), é preciso olhar para essa questão sob o viés de uma complexa gestão do poder cujos efeitos perpassaram inescapavelmente pelo corpo carismático do ex-presidente Lula.

O breve ensaio Dilma Rousseff e o ódio político elabora um panorama que ajuda a explicar a crise na quarta administração petista, articulando elementos da manipulação simbólica, do desejo, da alucinose e da recusa que passam a entrar em conflito no espaço público nacional. O autor identifica o esfacelamento do mundo petista sob o comando de Dilma Rousseff a partir de escolhas político-econômicas, como a redução histórica dos juros bancários, que fomentaram o estado de ebulição política atual e desembocaram em uma nova ordem de violências que, alimentada pelo ódio, nutriu evocações militaresautoritárias e um apedrejamento antidemocrático como sinal de desespero e desacordo. Entendendo a convocação e a dominação carismática do político como base na captura de nossos desejos, o autor acentua complexos pactos de comunicação objetivando frisar a completa posse de carisma de Lula contrapondo-se à integral ausência de empatia de Dilma. A despeito disso, a opção por Dilma materializaria um desejo lulista de que não exista sombra política à sua altura no Partido dos Trabalhadores. Ante esse déficit carismático, Ab'Saber liga Dilma ao epíteto anti-príncipe maquiavélico, qualificando-a como a responsável por transformar a política em gerência, e, nesse sentido, ela é herdeira de um moralismo técnico que enreda empresas nacionais, sobretudo as empreiteiras, em um modo perverso de jogar com o Estado e com a política. A despeito da predileção pela técnica para a gestão do Estado brasileiro, o autor qualifica Dilma como um "José Serra de saias", sobretudo devido ao grande mau humor e à forte tendência ao dissenso.

O fato é que a inabilidade radical com o outro, que seria uma característica dilmista, é exatamente o inverso da política por sedução de Lula. Esse espelho invertido entre os líderes petistas desvela crises que culminam no ódio como a grande paixão política contemporânea nacional. Nesse caldo de insatisfação, destaca-se que Dilma enfrenta a mais forte objeção que se poderia esperar: a oposição direta do capital financeiro e seu pacto pelo rentismo. Considerando a Copa do Mundo e as Olimpíadas como timoneiras ordenadoras de ações públicas e legislações locais, salienta-se que, apesar das Jornadas de Junho, o Brasil havia se tornado uma fábrica de consentimento (ARANTES, 2013, p.73). Como destaca Ruy Braga (2015, p.47), esse consentimento, base da hegemonia lulista, permitiu a construção de uma relativa pacificação social, pois contava com a concordância passiva das classes subalternas e ativa das direções empresariais. Com a apertada vitória petista em 2014, esse acordo implodiu e surgiram tensões políticas e clivagens sociais reais com convocações à direita e à esquerda, dando origem a um novo agente social: o homem conservador médio. Para o autor, essa nova figura é 
antipetista por tradição e anticomunista por natureza arcaica brasileira mais antiga - um homem de adesão ao poder por fantasia de proteção patriarcal e agregada, fruto familiar do atraso brasileiro no processo da produção social moderna (p.35).

Ab'Sáber ressalta que a luta anticomunista surge como uma espécie de fantasmagoria limite. Para o antipetista, portanto, bastaria atribuir ao governo o epíteto de estalinista ou bolivariano - que automaticamente estaria livre de explicar o real sentido da política brasileira. Sob essa clivagem, a obra vislumbra a emergência de uma tea partização do espaço público nacional. Esse movimento busca a submissão ao mercado e, por outro lado, carrega em seu DNA delírios moralistas próprios do velho anticomunismo brasileiro. Nesse neo-transe, o país vai às ruas em uma ritualização de ódio e de intolerância antidemocrática. Ministros são agredidos em hospitais e restaurantes. Cantores simpáticos ao petismo são assediados em bares e nas redes sociais. Militantes são "convidados" a se mudar para Cuba. Agora desfilam pelas ruas brasileiras elegantes socialites e convictos defensores de ditaduras bradando "intervenção militar constitucional". Para Ab'Sáber, essas manifestações, além de atrasadas, significam a regressão da política e das diferenças, implicando em gozos baixos, em gozos de ódio. A luta contra um comunismo inexistente seria, assim, uma política de direito ao ódio. No limite, trata-se do ódio à democracia (RANCIÈRE, 2015). O fato é que essa paixão alimenta uma nova organização à direita do espectro político e está nas ruas, feroz nas críticas ao governo. O deputado Eduardo Cunha surge como o rosto mais proeminente, sobretudo quando sepulta as discussões sobre o aborto e sobre a descriminalização das drogas e, por outro lado, celebra a proposta de diminuição da maioridade penal e a ampliação da terceirização do trabalho. Desse modo, vê-se surgir um populismo conservador que tem rescaldo em uma nova elite telerreligiosa, empreendedora e pós-moderna a bradar contra a corrupção vestindo camisas da CBF e tirando selfies com policiais.

Por fim, a obra joga luz na judicialização da política brasileira, situando o juiz Sérgio Moro como o capitão do time que aprofunda a deslegitimação do sistema político. Nesse sentido, os termos milionários e poderosos na cadeia parecem irromper como as novas tônicas desse Brasil que antagoniza emancipação e regulação, democracia e militarismo, esperança e ódio.

Filipe Aquino é publicitário e doutorando em Sociologia pela Universidade do Porto, Portugal.

filipecaquino@gmail.com 


\section{Referências}

ARANTES, P. E. Cidades Rebeldes. Passe Livre e as manifestações que tomaram as ruas do Brasil. São Paulo: Boitempo, 2013.

BRAGA, R. Contornos do pós-lulismo. Revista Cult. São Paulo, n. 206, ano 18, p.46-49, out 2015.

RANCIÈRE, J. O ódio à democracia. São Paulo: Boitempo, 2014. 